\title{
Conversion to organic farming: a dynamic opportunity for Pakistani smallholders of fresh fruit
}

\author{
Ali Abid ${ }^{1}$ (iD) Shang Jie ${ }^{1^{*}}$ (D) \\ ${ }^{1}$ Agricultural Economics and Management, College of Economics and Management, Northeast Forestry University, Harbin, 150040, \\ Heilongjiang, China. E-mail: shangjie2005@126.com. "Corresponding author.
}

ABSTRACT: Exporting the organic fresh fruit (FF) to Europe and America could be regarded as great opportunity for smallholders and suppliers of Gilgit Baltistan, Pakistan. Yet, the global organic farmland and the number of organic producers are continued to grow. To date, little is known about the behavior of Pakistani farmers towards organic fresh fruit production. This study examined the factors that influence the decision-making of fresh fruit smallholders concerning the conversion to organic farming (COF). This study uses Ajzen's theory of planned behavior (TPB) to predict the behavior of Pakistani smallholders of fresh fruit. Path analysis examined the utility of the extended version of the TPB model to anticipate 277 small-scale farmers' behavioral intentions towards the adoption of organic farming (AOF) and their prospect of converting their farm to organic produce within the next three years. The present study reported that the smallholders' attitude (ATT), subjective norms (SN), perceived behavior control (PBC), and farmer's group participation (FGP) were positively correlated with farmer's intention to adopt organic farming, while group participation of farmers has significant correlation with their behavior regarding production of organic fruits. The present study justifies using the model of farmers'group participation in policies that deliberately cheer up smallholders of fresh fruit to adopt organic farming, to raise farm incomes and to alleviate poverty.

Key words: organic farming, farm conversion, theory of planned behavior, PLS structural equation modeling, group participation.

Conversão para a agricultura orgânica: uma oportunidade dinâmica para pequenos produtores de frutas frescas do Paquistão

RESUMO: Exportar a fruta fresca orgânica (FF) para a Europa e América pode ser considerada uma grande oportunidade para pequenos proprietários e fornecedores de Gilgit Baltistan, Paquistão. No entanto, as terras agrícolas orgânicas globais e o número de produtores orgânicos continuam a crescer. Até o momento, pouco se sabe sobre o comportamento dos agricultores paquistaneses em relação à produção de frutas frescas orgânicas. O objetivo deste estudo, portanto, foi examinar e determinar os fatores que influenciam a tomada de decisão dos pequenos produtores de frutas frescas sobre a conversão para a agricultura orgânica (COF). Este estudo usa a teoria do comportamento planejado de Ajzen (TPB) para prever o comportamento dos pequenos produtores de frutas frescas do Paquistão. A análise de caminho examinou a utilidade da versão estendida do modelo TPB para antecipar as intenções comportamentais de 277 agricultores de pequena escala em relação à adoção da agricultura orgânica (AOF) e sua perspectiva de converter sua fazenda em produtos orgânicos nos próximos três anos. O presente estudo descobriu que a atitude dos pequenos proprietários (ATT), as normas subjetivas (SN), o controle do comportamento percebido $(P B C)$ e a participação do grupo de agricultores (FGP) foram positivamente correlacionadas com a intenção do agricultor de adotar a agricultura orgânica, enquanto a participação do grupo de agricultores correlação significativa com seu comportamento em relação à produção de frutas orgânicas. O presente estudo justifica o uso do modelo de participação de grupos de agricultores em políticas que encorajam deliberadamente os pequenos produtores de frutas frescas a adotar a agricultura orgânica, para aumentar a renda agrícola e diminuir a pobreza.

Palavras-chave: Agricultura orgânica, conversão de fazendas, teoria do comportamento planejado, Modelagem de equações estruturais PLS, participação em grupo.

\section{INTRODUCTION}

Organic farming is at the forefront of the sustainable agriculture movement (HOME et al., 2018) and has captured growing attention all over the world (ISSA \& HAMM, 2017; JOUZI et al., 2017; KHANAL; MISHRA \& HONEY, 2018). Global organic farmland expanded by 11.7 million hectares in 2017, which is a remarkable increase in history.
Nearly a quarter of the world's organic farmland and more than 87 percent of the producers were reported to come from the developing countries. The increase of organic farmland in some developing nations has been driven primarily by the rising exports of organic foods to developed countries, such as the United States of America and the European Union (AHLEM \& HAMMAS, 2017; KHANAL; MISHRA \& HONEY, 2018; RECHE et al., 2019; WILLER \& 
LERNOUD, 2019). The sales of organic food totaled $\$ 97$ billion in 2017, compared to $\$ 18$ billion in 2000 , growing more than fivefold over the past 17 years (WILLER \& LERNOUD, 2019). More recently, the organic food production has lagged due to demand and supply issues, hence there are likely to be more producers contributing to the robust industrial growth (ARUMUGAM et al., 2018).

This research aimed to predict the intentions of Pakistani farmers of fresh fruit (FF) to adopt organic farming, which offers excellent prospects for export revenue generation. In 2017, Pakistan exported about 439.8 metric tonnes of fresh fruit worth \$325.6 million to the European Union and the USA(DAR, 2017). Although, Europe and America are potentially more lucrative markets for high-quality fresh fruit, this could be a dynamic opportunity for Pakistani producers and suppliers of FF to export organic produce to Europe and USA, where recent production shortages have taken place. Given the growing prevalence of organic products in developing countries, there is a dire need to expand the organic production in Pakistan. The Pakistani policymakers have considered the advantages of organic farming in the recent decade, and the Independent Executive Committee of Organic Farming was established by the National Agriculture Research Centre (NARC). NARC has played a vital role in strengthening organic farming and providing pieces of training to 5000 farmers and students (ABID et al., 2020 \& AKRAM et al., 2019). Despite this training, organic farming in Pakistan has developed much more slowly than in other developing countries, which indicates that Pakistan's fresh fruit farmers have not fully converted their farms to organic farming, without potential to export organic food. More importantly, considering the farmers of fresh fruit to adopt organic farming is essential for better livelihood and poverty alleviation (HENSON; MASAKURE \& CRANFIELD, 2011; KHAN; AHMAD \& AMJAD, 2013; RASUL \& HUSSAIN, 2015).

Several studies have examined the factors that can influence, motivate or inhibit smallholders from adopting organic farming. In general, it is believed that social, economic, and psychological factors have affected the decisions of farmers to convert to organic farming (BOLWIG; GIBBON \& JONES, 2009; DAXINI et al., 2019; DESSART; BARREIRO-HURLÉ \& VAN BAVEL, 2019; HOME et al., 2018). These factors are comprised of maintenance of family farm (BOUTTES; DARNHOFER \& MARTIN, 2018), the farm's characteristics (CHMIELINSKI et al., 2019), the farm's economic potential (KERSELAERS et al., 2007), environmental concerns (MEIER et al., 2015), employment potential (FINLEY et al., 2018), reduction of nitrogen and pesticide use (MULLER et al., 2017), maintenance of the family farm's ecological balance (NELSON \& STOCK, 2018), provision of healthy food for the family (KASHIF et al., 2020), and protection of local biodiversity from further degradation (CHAPPELL \& LAVALLE, 2011). Other studies have demonstrated that farmers are motivated to adopt organic production not only for economic and financial reasons (LUND; HEMLIN \& LOCKERETZ, 2002 \& PADEL, 2001), but also for health, ideological and philosophical reasons (RIGBY; YOUNG \& BURTON, 2001; WILIER \& GILLMOR, 1992). In other studies, in addition to economic factors, moral values and social norms have been identified to play an important role in affecting the smallholders, in making decisions, to adopt organic farming (KOESLING; FLATEN \& LIEN, 2008 \& MZOUGHI, 2011). Much of the research in developing countries has; therefore, focused on economic rationales for conversion to organic production, as it is the most significant factor, especially for organic products intended for export (BOLWIG; GIBBON \& JONES, 2009; HATTAM; LACOMBE \& HOLLOWAY, 2012 \& OELOFSE et al., 2010).

Besides the advantages of organic farming, some critics in developed countries argued that it may have lower productivity and would need more land to produce the same quantity of food as conventional agriculture (SEUFERT; RAMANKUTTY \& FOLEY, 2012). The other group (the entrepreneurs) voiced more criticism towards organic farming and considered making money through conventional farming (LUND, 2006). As a result, the excessive use of pesticides have spread rapidly and become an indispensable element for farmers worldwide (MONFARED; YAZDANPANAH \& TAVAKOLI, 2015). Therefore, the root of the problem is related to farmers' decision-making because the factors that motivate the conversion to organic agriculture in the developing countries were generally dissimilar to those in developed countries (ISSA \& HAMM, 2017). Therefore, the study of ISSA \& HAMM (2017) is more consistent with thought according to which Syrian farmers of fresh fruits anticipated to adopt organic farming when the opportunity of a price premium for organic products arises.

Although, the concept of organic farming is well established in the literature currently, as a matter of fact, our comprehension of what makes Pakistan's 
fresh fruit farmers to adopt organic farming practices still remain superficial. Therefore, the present study used the psychological model to examine whether or not Pakistani fresh fruit farmers could consider converting their farms to organic production. The social psychologists have developed many models to better understand and predict human behavior during the last three decades (YAZDANPANAH \& FOROUZANI, 2015). These models are labeled as the Expectancy-value, specially designed to predict and understand human behavior (ARVOLA et al., 2008). There are several psychological theories to explain health-related behavior such as the motivation protection theory (ROGERS, 1983), the health belief model (ROSENSTOCK, 1974 \& YAZDANPANAH; FOROUZANI; HOJJATI, 2015), social cognitive model (BANDURA, 1986) or Ajzen's theory of reasoned action (TRA) and its successor theory of planned behavior (AJZEN, 1991). Therefore, the present research was based on Ajzen's theory of planned behavior, which is successfully applied in predicting farmers' behavior for conversion to organic farming (ASADOLLAHPOUR et al., 2015) and appropriate to investigate the relationship between attitudes and behavior (WEBB \& SHEERAN, 2006). However, the various scholars criticized the theory of planned behavior due to insufficient consideration of other constructs that are related to human behavior (ARMITAGE \& CONNER, 2001; BURTON, 2004). Therefore, by extending the theory of planned behavior, we construct a model for decision-making of smallholders to adopt organic farming. With the integration of psychological and external factors into the same analytical framework, this model provides more reasonable guidelines for policymakers. Therefore, the present research determined the factors that could motivate conventional farmers to carry out organic production, and the findings of the study could help the government to adopt some amicable and proactive policies to support the participation of smallholder farmers in adopting organic farming.

The conceptual model and development of hypothesis Theory of the planned behavior (TPB)

Ajzen's theory of planned behavior (TPB) is an extension of the theory of reasoned action, to understand and predict behaviors (AJZEN, 1991). Ajzen's TPB is considered to be a good predictor for performing a particular behavior. The theory assumes that individuals' intention to perform a particular behavior is affected by individuals' attitudes (i.e., attitude towards conversion to organic agriculture in the context of the current study), perceived behavior control (PBC), and subjective norms ( $\mathrm{SN}$ ) i.e. the importance of others' opinions (Figure 1). The TPB model successfully used in various agriculturerelated fields to perceive a range of intention and behaviour with regard to (e.g.), uptake environmental conservation behavior at farms (DENG et al., 2016), for adoption of organic farming (BOUTTES; DARNHOFER \& MARTIN, 2018; DAXINI et al., 2019) and has been frequently used to study farmer decision-making to adopt new technology in agriculture (ISSA \& HAMM, 2017).

\section{Attitude}

Concerning the hypothesis of the model, the attitude of an individual is a belief-based factor that influences the intention to perform the particular behavior. The attitude could be the favorable or unfavorable appraisal of the behavior. It defines the extent to which a person has a positive or negative belief to perform the behavior in question (AJZEN $\&$ FISHBEIN, 2005). In the past, several agricultural researches have also investigated the role of attitude on behavioral intentions. These studies found attitude is influential in farmer's decision making to adopt organic farming (ISSA \& HAMM, 2017; LÄPPLE \& RENSBURG, 2011). Based on what is described, it is urged that:

Hypothesis 1: Smallholder's attitude is positively associated with his behavioral intention for conversion to organic farming.

\section{Subjective norms}

The subjective norms related to the perceived social pressure to engage or not to engage in the given behavior. The SN expresses individual's perception of how important others are and to which extent he or she approves or disapproves of the behavior (FISHBEIN \& AJZEN, 2011). The study of ASADOLLAHPOUR et al., (2015) have reported that subjective norms significantly and positively influence the intentions of paddy farmers to adopt organic farming. In the context of present work, subjective norms seem to play an essential role in shaping smallholder's intention to perform the specific actions without caring others. Based on the argument, so far; it is hypothesized that:

Hypothesis 2: Subjective norms are significantly associated with farmers' intentions for conversion to organic farming.

\section{Perceived behavioral control}

The third determinant of the TPB model is $\mathrm{PBC}$ that defines as a person's perception of the 


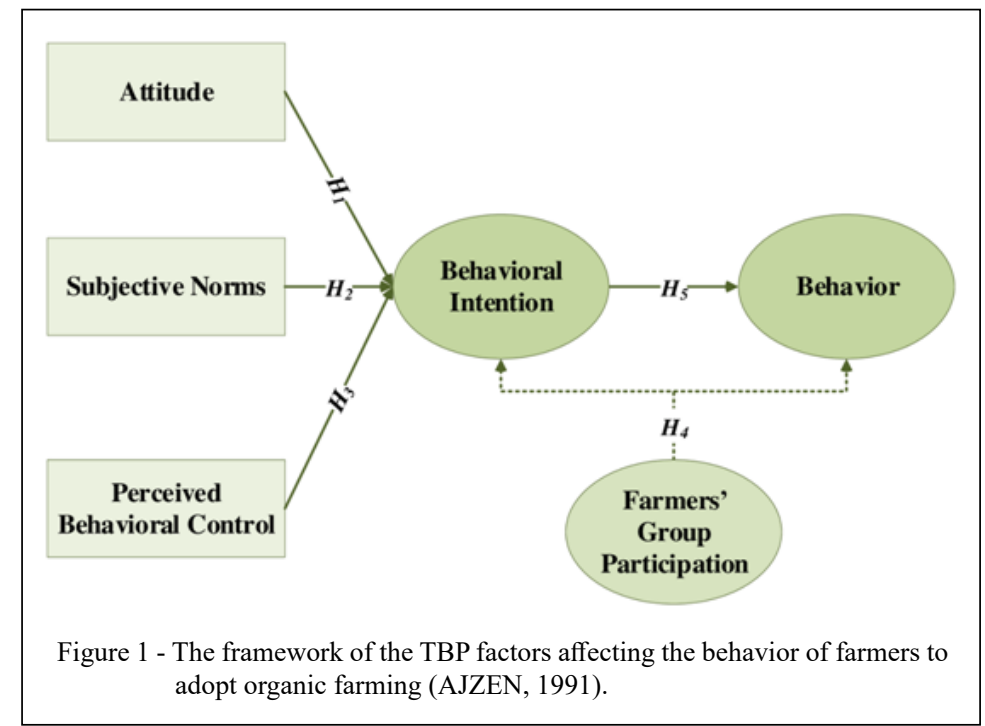

ease or difficulty to execute the behavior in question. The PBC concerns with individuals' judgment about the abilities to involve in a specific behavior (AJZEN \& DRIVER, 1992). The PBC reflected a person's perceptions of control over performance of a focal behavior (DENG et al., 2016). In the context of this study, the greater the PBC, the stronger smallholder's behavioral intention to adopt organic farming.

Hypothesis 3: Perceived behavioral control is significantly associated with the farmers' intentions for conversion to organic farming.

While the success of the theory of the planned behavior in predicting intentions has been established (LIAO; CHEN \& YEN, 2007; NIGBUR; LYONS \& UZZELL, 2010); however, this theory has been criticized as being insufficient for predicting the other con- structs that may be associated with human behavior (ARMITAGE \& CONNER, 2001; BURTON, 2004). Accordingly, AJZEN (1991), p.199 claimed that the TPB model was "in principle, open to the inclusion of additional predictors if it can be shown that they capture a significant proportion of the variation in intention or behavior". While it is not mandatory to include new variables in all situations, they can be meaningful in some instances (BURTON, 2004). This possibility led many researchers to make changes to the standard TPB model by adding anticipated variable that may influence the human behavior. Building on this criticism, this study has constructed a model of farmers' group participation in the standard TPB model to better understand of the behaviors of Pakistani farmers of fresh fruit.

\section{Farmers' group participation}

Farmers' group participation (FGP), in developing countries, has served many of the functions that elsewhere had served by the formal institutions (FERRARA, 2002). In Pakistan, most of the fresh fruit are grown by the small- scale farmers. The lack of financial access limits the range of services, and credits required for the certification and inspection cost. The group participation usually goes hands in hands with contract farming that provides an initial approach to exporters and group certification. CÁCERES (2005) has stated that FGP allowed farmers to join contract for reduction of certification cost and access to export markets. In developing countries, FGP is involved based on two steps decision "certification according to the organic standard" and "contract with an exporter" (KLEEMANN; ABDULAI \& BUSS, 2014). The study of KLEEMANN \& ABDULAI (2013) reported that the farmers who had participated in group were highly willing to adopt organic farming. Therefore, the authors wanted to test whether:

Hypothesis 4: Farmers' group participation positively associated with the behavioral intentions to adopt organic farming and behavior to produce organic fruits.

\section{Behavioral intention}

Behavioral intention refers to a person's subjective probability to perform the behavior of interest. Ajzen defined BI as an indicator of "how hard people are willing to try" and "how much of an effort they are planning to exert" (AJZEN, 
1991). Consistent with this, intentions are supposed to captivate the motivational factors that persuade a behavior. Therefore, Ajzen judgments more constant with the thought, according to which, given an adequate degree of actual control over behavior, a person is anticipated to execute the intention when the opportunity occurs (AJZEN, 1985). The stronger the behavioral intentions, the more likely an individual will be able to take action. Therefore, we hypnotize:

Hypothesis 5: Farmers' intentions to adopt organic farming significantly influence the behavior to produce organic fruit.

\section{The variables and measures}

All the constructs of the model were measured by using multiple indicators used in the previous research. First, for the assessment of attitude (ATT), four of Ajzen's proposed adjectives were used; "good idea, beneficial, important, and wise" (AJZEN, 2001) in the appropriate phrases. Second, for the subjective norms, two terms were used to assess the importance of the opinion of others (e.g. relative, colleagues or family). The survey asked whether it was "preferred " or "expected " (AJZEN \& MADDEN, 1986) that they should pursue the behavior regarding the adoption of organic farming. Third, to assess PBC, two terms were used. The survey asked the farmers about whether they were "confident " and "had control " (AJZEN, 2002 \& AJZEN; DRIVER, 1992) for executing the decision of conversion into organic farming. Fourth, discrete value of 1 or 2 used to measure the variable of "Farmers Group Participation (FGP)." Most recently, the study of HOU \& HOU (2019) have revealed that farmer's participation in group farming positively related to the behavior of low-carbon agriculture in China. The primary purpose of farmers' group participation model is to determine whether farmers participate in a contract (e.g., such as contracting with an exporter and reducing certification cost), or not? Therefore, this study introduces the construct of farmers' group participation in the standard TPB model. To assess the willingness, the respondents were asked to rate their decision on the scale; to what extent are they likely or not likely to participate in the group (Table 1).

Fifth, three terms were used to evaluate the farmers' intentions. The survey asked the respondents how much longer they "would try," or "intend to" try, or "make an effort " (AJZEN \& DRIVER, 1992) to adopt organic farming. To measure the constructs of ATT, SN, $\mathrm{PBC}$, and $\mathrm{BI}$, a bipolar Likert scale was applied, ranging from 0 to 4, with 0 meaning " strongly disagree" and 4 meaning "strongly agree." Finally, given the practical situation to adopt organic farming in Pakistan, the behavioral statements were adopted from the study of Issa (2016). "How likely do you think production of organic fruits on your farm, within the next three years?", "Do you think adoption of organic farming on your farm is possible within the next three years?" and "How probable is that you will start conversion to organic farming within the next three years? "To measure this construct, a bipolar Likert scale was applied, ranging from 0 to 4 , "very unlikely" to "very likely", "definitely impossible" to "definitely possible" and "highly probable" to "not probable at all”, respectively, (Table 2).

This study also used the scale of 'principle of compatibility' that was introduced by AJZEN \& FISHBEIN, (2005), in which "a single behavior can be viewed as involving an action directed at a target, performed in a given context, at a certain point in time." The action was specified as "production of organic fruits,' the target was the "organic fruits," the context was the "certain farm," and the duration of the activity time was identified as "three years."

\section{Data collection and analysis Site for the study}

The study was conducted in the three districts (Skardu, Astore, and Diamir) of Gilgit-

Table - 1 Example scenario for measuring farmers' group participation.

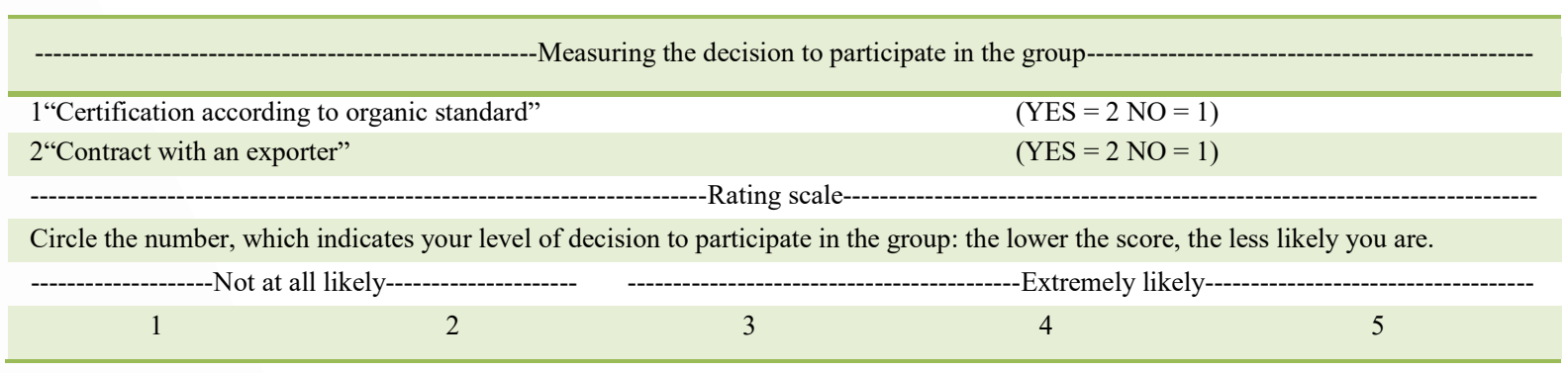

Ciência Rural, v.51, n.9, 2021. 
Table 2 - Objects used for the evaluation of TPB model constructs.

\begin{tabular}{|c|c|}
\hline Items & Measurement objects \\
\hline ATTw & I believe that producing organic fruits on the farm is a good idea \\
\hline ATTx & In my opinion, the production of organic fruits in the farm is beneficial \\
\hline ATTy & For me, the production of organic fruits on the farm is important. \\
\hline ATTz & In my opinion, the production of organic fruits in the farm is wise. \\
\hline $\mathrm{SNw}$ & My family members would expect me to produce organic fruits on the farm. \\
\hline $\mathrm{SNx}$ & My friends would favor the idea of the farm producing organic fruits. \\
\hline $\mathrm{PBCw}$ & I feel confident in producing organic fruits on the farm. \\
\hline PBCx & I have control over whether or not to produce organic fruits on the farm. \\
\hline FGPw & The decision to participate in the group, "certification according to organic standard" $(2=y e s ; 1=$ no $)$ \\
\hline FGPx & The decision to participate in the group, "contract with an exporter" $(2=\mathrm{yes} ; 1=$ no) \\
\hline BHR_INTw & I intend to produce organic fruits on the farm. \\
\hline BHR_INTx & I will use every effort to produce organic fruits on the farm. \\
\hline BHR_INTy & I am willing to produce organic fruits at the farm. \\
\hline $\mathrm{BHRw}$ & How likely do you think the production of organic fruits on your farm, within next three years? \\
\hline BHRx & Do you think the adoption of organic farming on your farm is possible within next three years? \\
\hline BHRy & How probable is that you will start the conversion to organic farming within next three years? \\
\hline
\end{tabular}

Note: BHR_INT = Behavioral Intention; ATT = Attitude; $\mathrm{SN}=$ Subjective Norms;

$\mathrm{PBC}=$ Perceived Behavioral Control; FGP $=$ Farmers' Group Participation; $\mathrm{BHR}=$ Behavior;

$\mathrm{W}=$ indicator variable $1 ; \mathrm{x}=$ indicator variable $2 ; \mathrm{y}=$ indicator variable $3 ; \mathrm{z}=$ indicator variable 4 .

Baltistan, Pakistan (Figure 2). In our study area, all farmers of fresh fruit would be considered to be smallscale producers who rely on considerable family labor inputs and rely on organic practices to grow fruits without the use of synthetic chemical inputs. In these counties, farmers have smallholdings and mainly rely on fruits production. The cultivated land is mostly comprised of slopes and valleys where the average

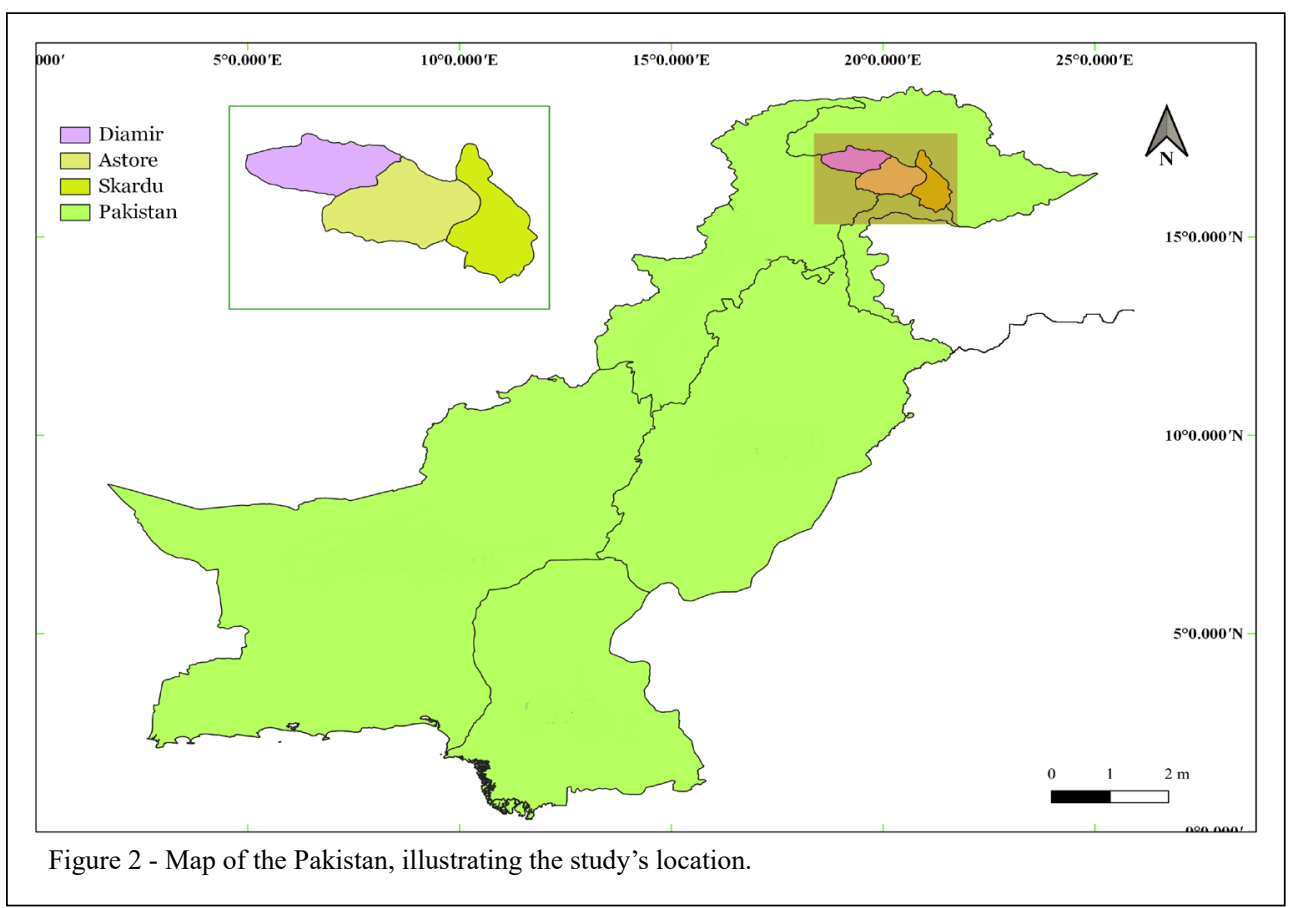

Ciência Rural, v.51, n.9, 2021. 
farm size is less than one hectare (KOUSAR et al., 2019). The region is leading in fruits production and country export (KOUSAR et al., 2019) where approximately more than 5,000 farmers are engaged in it (CARMELO, 2019).

\section{Questionnaire and sample}

A specifically designed questionnaire that was originally written in English was translated into Urdu (the national language), to ask about the behavior of farm owners. The questionnaire was designed on an ordinal scale as suggested by AJZEN, (2006) so that the responses could be quantified. It was divided into three parts. The first part was connected to the farm and attributes, the second section asked questions about the farmers' behavior towards conversion to organic farming, while the third section asked questions related to their knowledge about organic farming. The cluster random sampling procedure was adopted in the 13 villages of the three districts. In the phase one, 13 clusters (i.e., small towns) located in the three districts were chosen. In the second stage farmers in each cluster were selected randomly. Inperson interviews were the primary method used because it allows for better understanding of the interviewees' worldview and behavior (LOCKE, 2001) and development of personal rapport in the survey environment (SZOLNOKI \& HOFFMANN, 2013). The respondents $(N=277$ in total) were usually the conventional farmers of fresh fruit. The sample size was within the suggested range of 100-400 (HAIR JR. et al., 2010) and larger than the suggested minimum of $90(\mathrm{~N}=50+8$ number of constructs $)$ (GREEN, 1991 \& TABACHNICK; FIDELL, 2014). Thus, the sample size $(\mathrm{N}=277)$ was sufficient for structural equation modeling. The survey was carried out from July 2018 to August 2018.

\section{Analysis and model specification}

Following the TPB, this study analyzed, the relationships between the constructs with multiple hypotheses through Structural Equation Modeling (SEM), by using SmartPLS 3 (v.3.2.8) and SPSS (ver. 25 ). The PLS-SEM has been used to analyze variancebased SEM, especially in the fields of business and social sciences (HAIR, et al., 2012 \& HENSELER, JÖRG; HUBONA \& RAY, 2016). It is appropriate for multivariate analysis (HAIR, JOSEPH F.; RINGLE \& SARSTEDT, 2013 \& PENG; LAI, 2012). The PLS-SEM is a useful method to understand farmers' behavior and decision-making. This study used the partial least square two-step method that was proposed by HENSELER (2017), to evaluate the measurement (outer model) and the estimation of the structural (inner model).
This research used the partial least square (PLS) structural equation modeling (SEM) technique for the data analysis owing to many reasons:

i. If the research objective is exploratory or confirmatory, select PLS-SEM (HAIR et al., 2017; HAIR; RINGLE \& SARSTEDT, 2011).

ii. If the goal is predicting or identifying the key drivers, select PLS-SEM (HAIR et al., 2017; HAIR; RINGLE \& SARSTEDT, 2011)

iii. If the study's objective is to explain the relationship between exogenous and endogenous constructs, select PLS-SEM (HAIR et al., 2017; HAIR; RINGLE \& SARSTEDT, 2011).

iv. If the scaling of responses is ordinal or nominal, select PLS-SEM (HAIR et al., 2017; HAIR; RINGLE \& SARSTEDT, 2011)

v. The structural or measurement models are complex, select PLS-SEM (HAIR et al., 2017; HAIR; RINGLE \& SARSTEDT, 2011).

To investigate the inherent relationship between farmers' adoption of organic farming and the influencing factors, this paper employed PLS structural equation modeling. This is a statistical tool to observe latent variables that are difficult to perceive directly. It is generally characterized by three matrix equations:

$\eta=\beta \eta+\Gamma \xi+\zeta$

In the structural model, $\xi$ is an exogenous latent variable (i.e., attitude, subjective norms, perceived behavioral control and farmers' group participation), and $\eta$ stands for endogenous latent variable (i.e., behavioral intentions and behavior). $\Gamma$ denotes the path coefficient to predict dependent variable $\eta$ from an independent variable $\xi$. $\zeta$ is a random error term associated with the prediction of a given dependent latent construct $\eta$.

$y=\Lambda_{y} \eta+\varepsilon$

$x=\Lambda_{x} \xi+\delta$

In the measurement model of SEM, $y$, is the indicator of latent endogenous variables (the $\eta$ 's), while $x$ are the indicators of exogenous constructs (the $\xi$ 's). $\Lambda_{y}$ and $\Lambda_{x}$ contains the $\lambda_{i}$ parameters, which are the coefficients involving to the latent and manifest variables. The error of measurement vector of $y$ is $\varepsilon$, and errors for measurement vector for $x$ is $\delta$ (Figure 3).

\section{RESULTS}

\section{Descriptive analysis of smallholders}

In table 3, the demographic information of the farmers is described. It indicates that in northern regions, the majority of the farms were run by men 


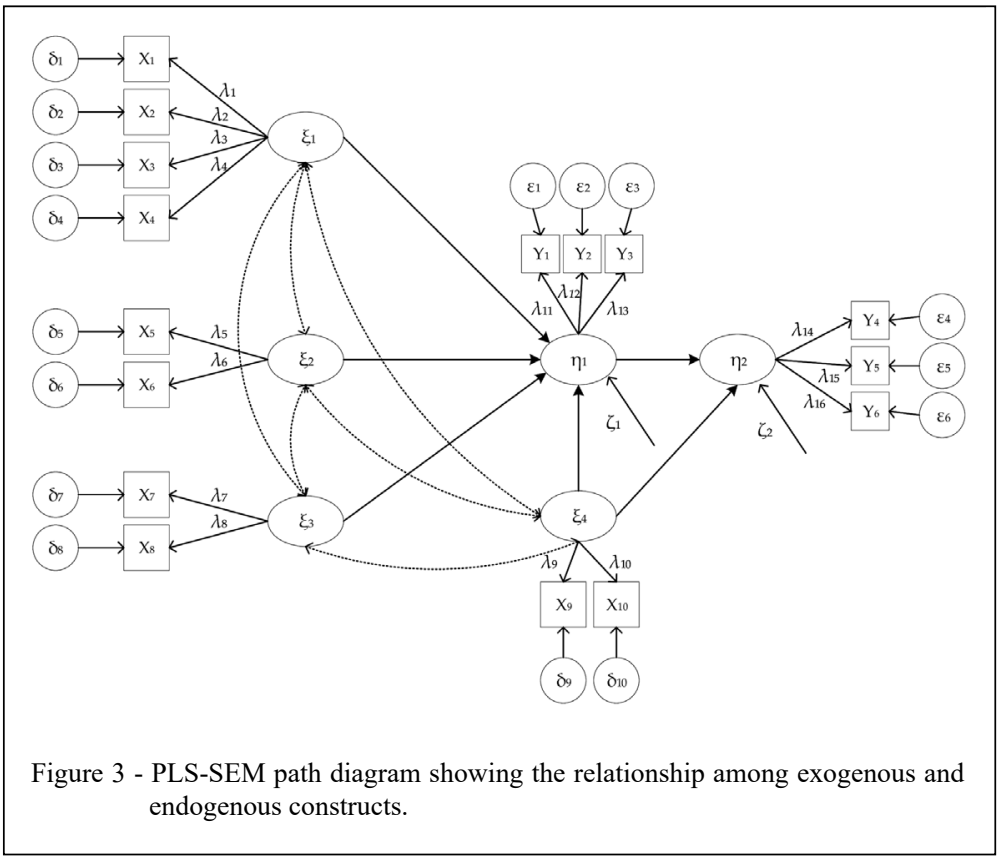

$95.7 \%$, while $4.3 \%$ of them were run by women. Regarding the age of respondents, there is a larger distribution of young farmers $42 \%$ among other categories of age. This shows that most of the younger farmers help out the families for earning livelihood besides their education. This survey demonstrated that the sample of farmers is an educated one, since $49.8 \%$ were graduated from university and college, while $39.4 \%$ have high and middle school level education. A significant respondent $(33.9 \%)$ has a

Table 3- Demographic information of fresh fruit farmers $(\mathrm{N}=277)$.

\begin{tabular}{|c|c|c|c|}
\hline Characteristics & & Frequency & Percentage \\
\hline \multirow{2}{*}{ Gender } & Male & 265 & 95.7 \\
\hline & Female & 12 & 4.3 \\
\hline \multirow{5}{*}{ Age } & Upto 29 & 115 & 41.5 \\
\hline & 30 to 39 & 81 & 29.2 \\
\hline & 40 to 49 & 50 & 18.1 \\
\hline & 50 to 59 & 20 & 7.2 \\
\hline & $60 \&$ above & 11 & 4 \\
\hline \multirow{5}{*}{ Education } & Primary & 30 & 10.8 \\
\hline & Middle Level & 52 & 18.8 \\
\hline & High Level & 57 & 20.6 \\
\hline & College Level & 71 & 25.6 \\
\hline & University \& above & 67 & 24.2 \\
\hline \multirow{3}{*}{ Household income (per month) } & $<15000$ Rs. & 94 & 33.9 \\
\hline & $15000-25000$ Rs. & 125 & 45.1 \\
\hline & $<25000$ Rs. & 58 & 20.9 \\
\hline
\end{tabular}

US\$ $1=160.25$ Rs. 
meager income, below 15000 rupees, while 45.1 $\%$ have an income ranging from 15000 to 25000 rupees, and $20.9 \%$ have above 25000 rupees. The average size of the farm is less than one hectare that provides a significant contribution in the livelihood of smallholders. The size of the farm ranging from less than 1 Kanal to relatively large farm 5 Kanals (1 Kanal $=0.0505$ Hectare .

Notably, in the survey results, $82 \%$ of interviewees expressed their knowledge about certification and inspection cost, required for organic farming. Approximately $70 \%$ of respondents said that they discussed organic farming with their colleague farmers and friends; , although $30 \%$ of the respondents said that they only did so infrequently. More than $90 \%$ farmers made positive statements about adoption of organic farming and perceived that it is profitable, as compared to conventional farming (Figure 4). Results of survey indicated that farmers with university qualifications had a good sense of organic farming and debated frequently. Overall, the interviewees explicitly expressed their substantial knowledge about organic farming.

Table 4, provides the descriptive statistics, which include the skewness, mean, kurtosis, and standard deviation. The values of skewness and kurtosis fell between positive and negative ones, thus confirming the normal distribution of data.

\section{The PLS-SEM outcomes from the TPB}

Measurement of the outer model

The outer model demonstrates the validity, internal consistency, and reliability of the observed and unobserved variables (HO, 2014). The internal consistency evaluates the construct's reliability, while the discriminant and convergent validity are based on the assessment of cogency (HAIR et al., 2012). According to HAIR, et al., (2012) values of observed variables with outer loading of 0.7 or higher are believed to be adequate. The third column in table 5 predicts that the loadings of all the measured variables were greater than the acceptable limit of 0.7. Composite reliability (CR) was regarded as a better evaluation than Cronbach's alpha of the constructs' internal consistency (FORNELL \& LARCKER, 1981). The findings of our study highlighted that all the constructs' composite reliability were higher than 0.80 , which met the acceptance criterion. Assessing internal consistency of the TPB constructs with Cronbach's alpha, all the scores were higher than the suggested value of 0.7 (BLAND \& ALTMAN, 1997). The average variance extracted (AVE) of the latent constructs were calculated to confirm the convergent validity (FORNELL \& LARCKER, 1981). According to HAIR, et al., (2012) the average variance extracted should be higher than 0.5 for all the constructs. As seen in table 5, all of the values of average variance extracted were higher than 0.5 .

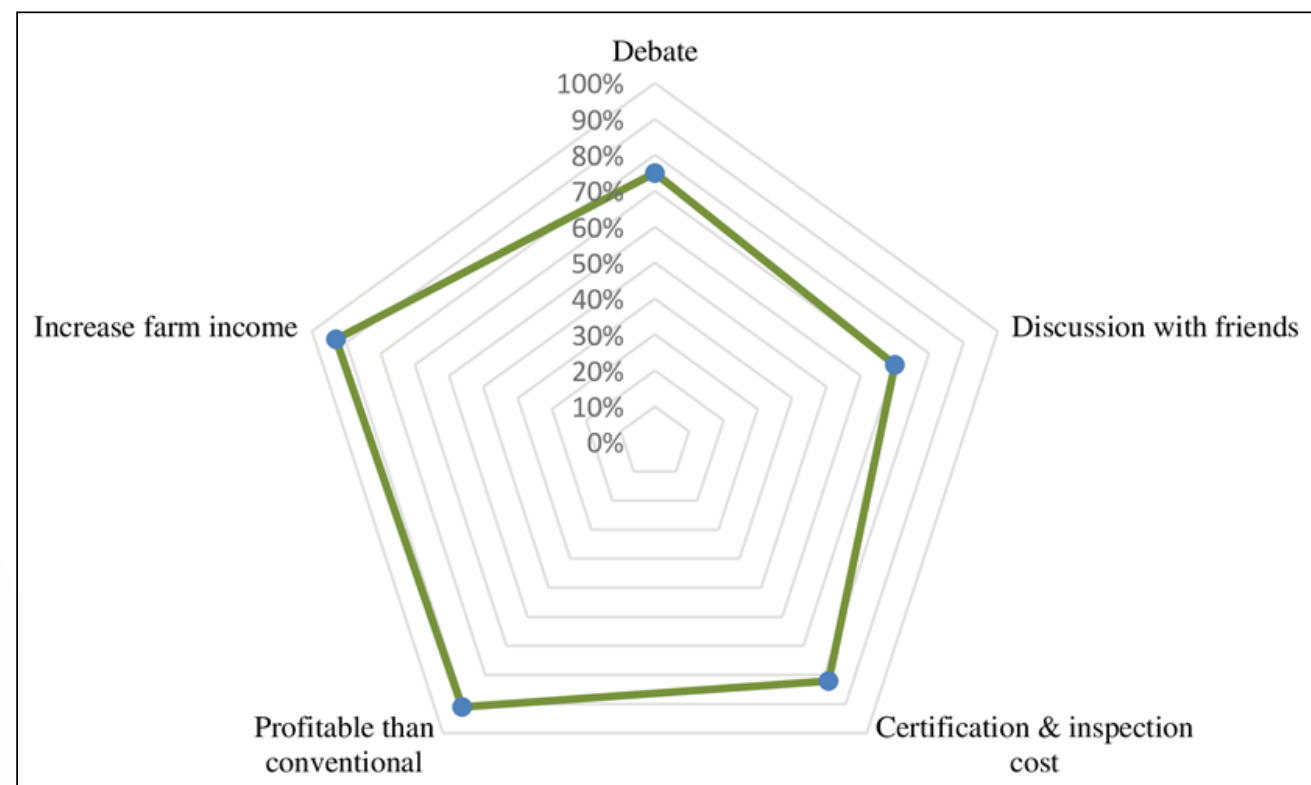

Figure 4 - Understanding the farmer's knowledge for conversion to organic farming. 
Table 4 - Descriptive statistics for normal distribution of data.

\begin{tabular}{|c|c|c|c|c|}
\hline Items & Mean & Standard Deviation & Skewness & Kurtosis \\
\hline $\mathrm{ATT}_{w}$ & 3.10 & 0.722 & -0.451 & -0.080 \\
\hline $\operatorname{ATT}_{x}$ & 3.08 & 0.796 & -0.670 & 0.137 \\
\hline $\mathrm{ATT}_{y}$ & 3.23 & 0.719 & -0.723 & 0.444 \\
\hline $\mathrm{ATT}_{z}$ & 2.96 & 0.871 & -0.479 & -0.484 \\
\hline $\mathrm{SN}_{w}$ & 3.06 & 0.794 & -0.548 & -0.148 \\
\hline $\mathrm{SN}_{x}$ & 2.94 & 0.864 & -0.391 & -0.603 \\
\hline $\mathrm{PBC}_{w}$ & 3.07 & 0.743 & -0.277 & -0.679 \\
\hline $\mathrm{PBC}_{x}$ & 3.09 & 0.787 & -0.611 & 0.005 \\
\hline $\mathrm{FGP}_{w}$ & 3.15 & 0.736 & -0.412 & -0.532 \\
\hline $\mathrm{FGP}_{x}$ & 3.14 & 0.755 & -0.494 & -0.338 \\
\hline BHR_INT ${ }_{w}$ & 3.27 & 0.622 & -0.261 & -0.625 \\
\hline $\mathrm{BHR} \_\mathrm{INT}_{x}$ & 3.22 & 0.713 & -0.355 & -0.983 \\
\hline 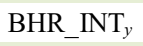 & 3.16 & 0.684 & -0.212 & -0.862 \\
\hline $\mathrm{BHR}_{w}$ & 3.00 & 0.814 & -0.534 & -0.168 \\
\hline $\mathrm{BHR}_{x}$ & 3.13 & 0.813 & -0.561 & -0.433 \\
\hline $\mathrm{BHR}_{y}$ & 2.86 & 0.948 & -0.375 & -0.816 \\
\hline
\end{tabular}

Note: $B H R \_I N T=$ Behavioral Intention; $A T T=$ Attitude; $S N=$ Subjective Norms;

$P B C=$ Perceived Behavioral Control; $F G P=$ Farmers' Group Participation; $B H R=$ Behavior;

$w=$ indicator variable $1 ; x=$ indicator variable $2 ; y=$ indicator variable $3 ; z=$ indicator variable 4 .

HAIR et al., (2014) \& HAIR; RINGLE \& SARSTEDT (2011) stated that to examine the discriminant validity in PLS-structural equation, an indicator's loading must be bigger than the loadings present on the remaining constructs. Table 6 demonstrated that the cross-loading of the described construct was higher than the loadings on the other constructs. Therefore, all the latent constructs had discriminated and convergent validities. Since the latent constructs in the TPB model were empirically distinctive from each other, this confirmed the Fornell-Larcker criterion.

\section{Analysis of inner or structural model}

The predictive relevancy and the relationships of the TPB model's constructs were measured through the $R^{2}, \beta$ value (path coefficient), $f^{2}$ (effect size), $Q^{2}$ (predictive relevancy of the TPB model), and goodness-of-fit (GOF) index.

Accessing the value of $R^{2}$, based on CHIN, (1998) opinion, a value of 0.67 is considered as substantial, a value of 0.33 is moderate, and a value of 0.19 is weak. In this study, the $R^{2}$ value of endogenous constructs of the TPB model, explain the variance of $63.2 \%$ in behavioral intentions and $61.8 \%$ in the behavior. Hence, the determination coefficient $\left(R^{2}\right)$ values in our study were between moderate to substantial.

Measuring the Path Coefficients $(\beta)$ The hypothesis' value was subjected to test $\beta$, as presented in table 7. The higher the value of $\beta$, the stronger the influence of the dependent constructs. To measure the significance of the hypothesis, a bootstrapping procedure was carried out CHIN, (1998), using 5,000 subsamples with no sign changes.

The $\beta$ value explained the variation in the endogenous construct for a unit variation in the exogenous construct (s). The greatest the $\beta$ value, more strongly is the influence on endogenous construct. Table 7 illustrates that the farmers' group participation and behavioral intention in the TPB model had the highest path coefficient value, which showed that FGP and BI constructs had a larger variance and strongest effect on the decision of conversion into organic farming. The attitude and $\mathrm{PBC}$ also predicted well in formulation of behavior, while subjective norms had least effect on the behavior to produce organic fruits. Therefore, all nine (9) path coefficients confirmed at least a p-value less than 0.05 . The study findings in table 7 show that 
Table 5 - Results of validity and reliability measures of the TPB model constructs.

\begin{tabular}{|c|c|c|c|c|c|}
\hline Latent Construct & Items & Loadings & AVE & Composite Reliability & Cronbach's Alpha \\
\hline \multirow{3}{*}{ Behavior } & $\mathrm{BHR} w$ & 0.863 & \multirow{3}{*}{0.739} & \multirow{3}{*}{0.895} & \multirow{3}{*}{0.824} \\
\hline & $\mathrm{BHR} x$ & 0.850 & & & \\
\hline & BHRy & 0.867 & & & \\
\hline \multirow{3}{*}{ Behavioral Intention } & BHR_INT $w$ & 0.789 & \multirow{3}{*}{0.602} & \multirow{3}{*}{0.919} & \multirow{3}{*}{0.869} \\
\hline & BHR_INTx & 0.791 & & & \\
\hline & BHR_INTy & 0.747 & & & \\
\hline \multirow{4}{*}{ Attitude } & $\mathrm{ATT} w$ & 0.816 & \multirow{4}{*}{0.673} & \multirow{4}{*}{0.892} & \multirow{4}{*}{0.838} \\
\hline & ATT $x$ & 0.817 & & & \\
\hline & ATTy & 0.792 & & & \\
\hline & $\mathrm{ATT} z$ & 0.856 & & & \\
\hline \multirow{2}{*}{ Subjective Norms } & $\mathrm{SN} w$ & 0.894 & \multirow{2}{*}{0.799} & \multirow{2}{*}{0.888} & \multirow{2}{*}{0.748} \\
\hline & $\mathrm{SN} x$ & 0.893 & & & \\
\hline \multirow{2}{*}{ Perceived Behavioral Control } & $\mathrm{PBC} w$ & 0.877 & \multirow{2}{*}{0.776} & \multirow{2}{*}{0.874} & \multirow{2}{*}{0.712} \\
\hline & $\mathrm{PBC} x$ & 0.885 & & & \\
\hline \multirow{2}{*}{ Farmers' Group Participation } & $\mathrm{FGP} w$ & 0.870 & \multirow{2}{*}{0.761} & \multirow{2}{*}{0.964} & \multirow{2}{*}{0.886} \\
\hline & FGP $x$ & 0.875 & & & \\
\hline
\end{tabular}

Note: $B H R_{-} I N T=$ Behavioral Intention; $A T T=$ Attitude; $S N=$ Subjective Norms;

$P B C=$ Perceived Behavioral Control; $F G P=$ Farmers' Group Participation; $B H R=$ Behavior;

$w=$ indicator variable $1 ; x=$ indicator variable $2 ; y=$ indicator variable $3 ; z=$ indicator variable 4 .

$A V E=$ Average Variance Extracted.

all the proposed hypotheses are accepted. Attitude positively influences behavioral intention $(\beta=0.232$, $\mathrm{T}=4.176, \mathrm{p}<0.000)$ and behavior $(\beta=0.195, \mathrm{~T}=$ $3.232, \mathrm{p}<0.000$ ), support to hypothesis 1 . Hypothesis 2 , which proposes that subjective norms influence the behavioral intention $(\beta=0.163, \mathrm{~T}=2.800, \mathrm{p}<$ $0.05)$ and behavior $(\beta=0.067, \mathrm{~T}=2.434, \mathrm{p}<0.05)$ are also accepted. PBC has a significant impact on behavioral intention $(\beta=0.249, \mathrm{~T}=4.281, \mathrm{p}<0.000)$ and behavior $(\beta=0.102, \mathrm{~T}=3.612, \mathrm{p}<0.000)$, thus supported hypothesis 3. As expected FGP has a significant and positive effect on behavioral intention $(\beta=0.252, \mathrm{~T}=3.885, \mathrm{p}<0.000)$ and behavior $(\beta=$ $0.544, \mathrm{~T}=10.888, \mathrm{p}<0.000)$. Therefore, hypothesis

Table 6 - Results of the Fornell and Larcker Criterion test.

\begin{tabular}{lccccc}
\hline & ATT & BHR & BHR_INT & FGP & PBC \\
\hline Attitude & $0.820 \varnothing$ & & & & \\
Behavior & 0.766 & $0.860 \varnothing$ & & & \\
Behavioral Intention & 0.701 & 0.723 & $0.776 \varnothing$ & $0.872 \varnothing$ \\
\hline Farmers' Group Participation & 0.691 & 0.732 & 0.714 & 0.719 & $0.881 \varnothing$ \\
\hline Perceived Behavioral Control & 0.718 & 0.731 & 0.711 & 0.748 & 0.696 \\
\hline Subjective Norms & 0.708 & 0.775 & 0.690 & $0.894 \varnothing$ \\
\hline
\end{tabular}

Note: BHR INT = Behavioral Intention; ATT = Attitude; $\mathrm{SN}=$ Subjective Norms;

$\mathrm{PBC}=$ Perceived Behavioral Control; FGP $=$ Farmers' Group Participation; $\mathrm{BHR}=$ Behavior;

$\varnothing$ FORNELL \& LARCKER (1981) suggested that each latent variable should have a correlation with its indicators more than other latent variables.

Ciência Rural, v.51, n.9, 2021. 
Table 7 - Results of path and coefficient of TPB model of fresh fruit farmers for conversion to organic farming in Pakistan.

\begin{tabular}{|c|c|c|c|}
\hline Path & Coefficients (Sample 277) & t-Statistics & p-Values \\
\hline $\mathrm{ATT}==>$ BHR & $0.195^{*}$ & 3.232 & 0.000 \\
\hline $\mathrm{ATT}==>$ BHR_INT & $0.232^{*}$ & 4.176 & 0.000 \\
\hline BHR_INT $==>$ BHR & $0.408^{*}$ & 7.345 & 0.000 \\
\hline $\mathrm{FGP}==>\mathrm{BHR}$ & $0.544^{*}$ & 10.888 & 0.000 \\
\hline $\mathrm{FGP}==>$ BHR_INT & $0.252^{*}$ & 3.885 & 0.000 \\
\hline $\mathrm{PBC}==>\mathrm{BHR}$ & $0.102^{*}$ & 3.612 & 0.000 \\
\hline $\mathrm{PBC}==>$ BHR_INT & $0.249^{*}$ & 4.281 & 0.000 \\
\hline $\mathrm{SN}==>\mathrm{BHR}$ & $0.067^{* *}$ & 2.434 & 0.015 \\
\hline $\mathrm{SN}==>$ BHR_INT & $0.163^{* *}$ & 2.800 & 0.005 \\
\hline
\end{tabular}

Note: BHR_INT = Behavioral Intention; ATT = Attitude; SN = Subjective Norms;

$\mathrm{PBC}=$ Perceived Behavioral Control; FGP = Farmers' Group Participation; BHR = Behavior;

${ }^{*}$ Significant at $\mathrm{p}<0.000$, and ${ }^{* *}$ significant at $\mathrm{p}<0.05$.

4 is supported. Behavioral intention has a positive impact on behavior $(\beta=0.408, \mathrm{~T}=7.345, \mathrm{p}<0.000)$, thus supporting hypothesis 5 .

The effect size $\left(f^{2}\right)$ measures the influence of each independent construct on the dependent construct. According to HENSELER; RINGLE \& SINKOVICS (2009) the values of $f^{2}>0.02, f^{2}>0.15$ and $f^{2}>0.35$ suggested weak, moderate and strong effect sizes, respectively. The $f^{2}$ values demonstrated the large, medium or weak effect of predictor latent variable at structural level. The results of the study in table 8 demonstrated that ATT, SN, PBC, and FGP latent constructs had small effect on the behavioral intention, while FGP and BI had moderate to strong effect on the behavior (Table 8).
The predictive relevance, $Q^{2}$ statistics are used to estimate the quality of PLS path model by using blindfolding procedures (TENENHAUS et al., 2005), and cross validated redundancy was performed. According to HENSELER, (2017) the value of $Q^{2}$ must be larger than zero for the specific endogenous construct. The table 8 demonstrated that the $Q^{2}$ values of behavioral intention and behavior were equal to 0.358 and 0.430 , which were larger than the limit of the threshold. This supported the predictive relevance of the path models for the endogenous latent construct.

The purpose of Standardized Root Mean Square Residual (SRMR) is to estimate the fitness of the model. According to HU \& BENTLER (1998), if

Table 8 - Effect size test of the TPB model of fresh fruit farmers for conversion to organic farming in Pakistan.

\begin{tabular}{|c|c|c|c|c|c|}
\hline Endogenous construct & $R^{2}$ & $Q^{2}$ & Relationship & $f^{2}$ & Effect size \\
\hline \multirow{2}{*}{ Behavior } & \multirow{2}{*}{0.618} & \multirow{2}{*}{0.431} & BHR_INT $==>$ BHR & 0.214 & Moderate \\
\hline & & & $\mathrm{FGP}==>\mathrm{BHR}$ & 0.250 & Moderate \\
\hline \multirow{4}{*}{ Behavioral Intention } & \multirow{4}{*}{0.632} & \multirow{4}{*}{0.358} & $\mathrm{ATT}==>$ BHR_INT & 0.056 & Small \\
\hline & & & $\mathrm{SN}==>$ BHR_INT & 0.026 & Small \\
\hline & & & $\mathrm{PBC}==>$ BHR_INT & 0.063 & Small \\
\hline & & & $\mathrm{FGP}==>$ BHR_INT & 0.061 & Small \\
\hline
\end{tabular}

Note: $\mathrm{R}^{2}=$ Coefficient of Determination;

$\mathrm{Q}^{2}=$ Predictive relevance of Model;

$\mathrm{f}^{2}=$ Effect Size. 
the values of SRMR less than 0.08 (SRMR $=<0.08$ ), the model is adequate to fit. In the present study the values of SRMR were 0.07 , which showed the TPB model had good fit, whereas the values of NFI and ChiSquare were equal to 0.722 and 746.785 (Table 9).

The complete analysis of both structural and measurement model has con- firmed the supremacy of both models. All of the proposed hypotheses were significant and hence were all accepted. The findings of our research strongly support our constructing model in the extended TPB that provides a more productive picture along with psychological and external factors that affecting the behavior to adopt organic farming.

\section{DISCUSSION AND CONCLUSION}

The present study examined the factors that influence the decision-making of fresh fruit smallholders concerning the conversion to organic farming (COF) with an extended TPB and PLS structural equation modelling. This paper is based on an extended theory of planned behavior and a survey of 277 small-scaled fresh fruits farmers conducted in three counties of Gilgit Baltistan Province, Pakistan. The current study enhanced the explanatory power of the TPB by incorporating a model of farmers' group participation that is supportive to join in group certification and access to the export market through contract farming. Therefore, the different components of the TPB model allowed enchanting and amalgamating a broad variety of knowledge required for decision-making, in a solo model. Overall, the TPB model successfully explained the behavior of farmers to produce organic fruits, with a total variation of $62 \%$.

Table 9 - Model fit summary showing the goodness of fit.

\begin{tabular}{|c|c|}
\hline SRMR & 0.071 \\
\hline d_ULS & 0.884 \\
\hline d_G & 0.483 \\
\hline Chi-Square & 746.785 \\
\hline NFI & 0.722 \\
\hline
\end{tabular}

Note: $\mathrm{SRMR}=$ Standardized root mean square residual; $\mathrm{d}_{\mathrm{ULS}}=$ squared Euclidean distanced; $\mathrm{d}_{\mathrm{G}}=$ geodesic distance; NFI $=$ Normed fit Index
The main findings of the study showed that ATT, SN, PBC, and FGP are significantly correlated with farmers' intention to adopt organic farming, whereas farmers' group participation more strongly correlated with their behavioral intention and actual behavior regarding organic fruits production. Accordingly, our constructing model of FGP with other components of TPB including, ATT, SN, PBC, substantially predicts farmer's behavior to produce organic fruits within the next three years. Further, the findings of the study showed that all suggested hypotheses were significantly supported. In the line with our findings, the study of ISSA \& HAMM, (2017) also found that farmers' attitudes significantly influence the intention to produce organic fruits and vegetables in Syria. In the same way, LÄPPLE \& RENSBURG, (2011) reported the positive attitude of farmers in the decision-making for adoption of organic farming. The study of TERANO et al., (2015)in Malaysia reported that ATT and PBC significantly affect the behavioral intention of farmers to adopt organic farming, however in their study; SN were not found meaningful. Following our findings, ASADOLLAHPOUR et al., (2015) and his colleague fellows has also explored that SN and PBC significantly influenced the intention of rice producers in Iran to adopt organic farming. In a similar manner, the study of KLEEMANN; ABDULAI \& BUSS (2014)have found that farmer-oriented group significantly influenced the Ghanaian farmers of pineapple to adopt certified organic farming.

Regarding the family and farm characteristics, farm owners with university and college-level education had particularly strong intentions towards the adoption of organic farming that was consistent with the study of ISSA \& HAMM, 2017) determined that Syrian farmers with higher education levels had stronger intentions to continue with organic farming. However, in contrast to our study, SARKER; ITOHARA \& HOQUE (2009) found that farmers in Bangladesh have lower educational levels. The farm owners in this study had significant emotions regarding their associations with the land; they wanted to preserve and produce organic fruits for better livelihood. These are good preconditions for farmers to increase the farm's income with certified organic products.

This study's analyzed the efficacy and use of TBP for investigating the intentions of the fresh fruit farmers towards the adoption of organic farming. It also sought to strengthen the explicatory power of the standard TBP model through the constructing of model: farmers' group participation. This study found 
that the TPB can effectively predict the farmers' behavior towards conversion to farming. The results of this study have demonstrated that farmers of fresh fruits in Gilgit Baltistan, Pakistan had significant and positive behavior towards conversion to organic farming, within the next three years. The model of farmers' group participation offers a successful approach to expand organic farming among Pakistani small-scaled farmers of fresh fruit at a lower cost.

The conclusions of the present study have implications for the Pakistani government and exporters, who are interested in exporting Pakistani organic produces. The findings emphasized the importance of incorporating FGP model into policies for promoting and encouraging small-scale farmers to produce organic fruits. The implication of the model gives access to the export markets through group certification and supportive for the enhancement of farm incomes and alleviation of poverty. The implications of our findings provided insight into the formation of financing model for the smallscale farmers of organic fruits and vegetables. This provides a solid foundation on which future research can be built, poverty-oriented promotion of organic value chains, to integrate poor small-holder producers of organic fruits among other value chain actors.

\section{ACKNOWLEDGEMENTS}

The authors are grateful to the Editor and anonymous reviewers whose comments have contributed to improving the quality of this paper. We would like to express our deep gratitude to all smallholders who provided valuable information for this study.

\section{DECLARTION OF CONFLICT OF INTEREST}

The authors declare no conflict of interest. The founding sponsors had no role in the design of the study; in the collection, analyses, or interpretation of data; in the writing of the manuscript, and in the decision to publish the results.

\section{AUTHORS' CONTRIBUTIONS}

All authors contributed equally for the conception and writing of the manuscript. All authors critically revised the manuscript and approved of the final version.

\section{REFERENCES}

ABID, Ali et al. Application of structural equation modelling to develop a conceptual model for smallholder's credit access: The mediation of agility and innovativeness in organic food value chain finance. PloS one, v.15, n.8, p.e0235921, 2020. Available from $<$ https://doi.org/10.1371/journal.pone.0235921>. Accessed: Jul. $12,2019$.
AHLEM, Zouari; HAMMAS, Mohamed Amine. Organic Farming: A Path of Sustainable Development. International Journal of Economics \& Management Sciences, v.6, n.5, p.1-7, 2017. Available from: <https://www.hilarispublisher. com/open-access/organic-farming-a-path-of-sustainabledevelopment-2162-6359-1000456.pdf $>$. Accessed: Jul. 12, 2019. doi: $10.4172 / 2162-6359.1000456$

AJZEN, Icek. CONSTRUCTING A THEORY OF PLANNED BEHAVIOR QUESTIONNAIRE. p. 1-7, 2006. Available from: $<$ http://people.umass.edu/ aizen/pdf/tpb.measurement.pdf $>$. Accessed : Jul. 12, 2019.

AJZEN, Icek. From Intentions to Actions: A Theory of Planned Behavior. Berling Heidlberg: SpringerVerlag, 1985. Available from: <https://link.springer.com/ chapter/10.1007/978-3-642-69746-3_2>. Accessed: Jul. 12, 2019. doi: 10.1007/978-3-642-69746-3 2.

AJZEN, Icek. Nature and Operation of Attitudes. Annual Review of Psychology, v.52, n.1, p.27-58, 2001. Available from: <http:// www.annualreviews.org/doi/abs/10.1146/annurev.psych.52.1.27>. Accessed: Jul. 15, 2019.

AJZEN, Icek. Perceived Behavioral Control, Self-Efficacy, Locus of Control, and the Theory of Planned Behavior. Journal of Applied Social Psychology, v.32, n.4, p.665-683, 2002. Available from: <https://onlinelibrary.wiley.com/doi/ abs/10.1111/j.1559-1816.2002.tb00236.x>. Accessed: Jul. 12, 2019. doi: $10.1111 /$ j.1559-1816.2002.tb00236.x.

AJZEN, Icek. The theory of planned behavior. Organizational behavior and human decision processes, v.50, n.2, p.179-211, 1991. Available from: <https://www.sciencedirect.com/science/ article/abs/pii/074959789190020T>.. Accessed : Jul. 12, 2019. doi: 10.1016/0749-5978(91)90020-T.

AJZEN, Icek; DRIVER, B. L. Application of the Theory of Planned Behavior to Leisure Choice. Journal of Leisure Research, v.24, n.3, p.207-224, 1992. Available from: <https://www.tandfonline. com/doi/abs/10.1080/00222216.1992.11969889>. Accessed: Jul. 12, 2019. doi: 10.1080/00222216.1992.11969889.

AJZEN, Icek; FISHBEIN, Martin. The Influence of Attitudes on Behavior. The handbook of attitudes. [S.1: s.n.], 2005. p.173-222. Available from: $<$ https://psycnet.apa.org/record/2005-04648-005>. Accessed: Jul. 12, 2019

AJZEN, Icek; MADDEN, Thomas J. Prediction of Goal-Directed Behavior: Attitudes, Intentions, and Perceived Behavioral Control. Journal of Experimental Social Psychology, v.22, n.5, p.453474, 1986. Available from: <https://psycnet.apa.org/record/200504648-005?utm_source $=$ mp-fotoscapes $>$. Accessed: Jul. 12, 2019.

AKRAM, Muhammad Waqar et al. An Assessment of Economic Viability of Organic Farming in Pakistan. Custos E Agronegocio on Line, v.15, n.1, p.141-169, 2019. Available from: $<$ http://www. custoseagronegocioonline.com.br/numero1v15/OK\%207\%20 farming\%20english.pdf $>$. Accessed: Jul. 12, 2019.

ARMITAGE, CHRISTOPHER; CONNER, Mark. Efficacy of the Theory of Planned Behaviour: A meta-analytic review. British Journal of Social Psychology, v.40, p.471-499, 2001. Available from: <https://bpspsychub.onlinelibrary.wiley.com/doi/ abs/10.1348/014466601164939>. Accessed: Jul. 12, 2019. doi: $10.1348 / 014466601164939$ 
ARUMUGAM, Surendran et al. Consumer's Preferences for Fresh Organic Produce in the Mid- Atlantic USA: An Econometric Analysis. Agricultural Research, 2018. Available from: $<$ https:// link.springer.com/article/10.1007/s40003-018-0357-z>. Accessed: Sept. 13, 2019. doi: 10.1007/s40003-018-0357-z.

ASADOLLAHPOUR, Ali et al. Modeling behavior pattern of Iranian organic paddy farmers. Paddy and Water Environment, v.14, n.1, p.221-229, 2015. Available from: $<$ https://link.springer. com/article/10.1007\%2Fs10333-015-0492-0>. Accessed: Sept. 15, 2019. doi: 10.1007/s10333-015-0492-0.

BLAND, J. Martin; ALTMAN, Douglas G. Statistics notes: Cronbach's alpha. England: [s.n.]., 1997. Available from: $<$ http:// www.jstor.org/stable/25173851>. Accessed : Jul. 12, 2019.

BOLWIG, Simon; GIBBON, Peter; JONES, SAM. The Economics of Smallholder Organic Contract Farming in Tropical Africa. World DEvelopment, v.37, n.6, p.1094-1104, 2009. Available from: <https://www.sciencedirect.com/science/ article/pii/S0305750X08003148?casa_token=isYE4U_a-IAAAAA:uxj9vgTJgP62g7i6r1tuAPZBn-0dnW86NTsyk1B QIVW65hyDUk8U2CcdXLNj1zNijj4gkFSJW>. Accessed: Jul. 12, 2019. doi: 10.1016/j.worlddev.2008.09.012.

BOUTTES, Maëlys; DARNHOFER, Ika; MARTIN, Guillaume. Converting to organic farming as a way to enhance adaptive capacity. Organic Agriculture, 2018. Available from: $<$ https:// link.springer.com/article/10.1007/s13165-018-0225-y>. Accessed: Jul. 12, 2019. doi: 10.1007/s13165-018-0225-y.

BURTON, Rob J. F. Reconceptualising the 'behavioural approach ' in agricultural studies : a socio-psychological perspective. Journal of Rural Studies, v.20, p.359-371, 2004. Available from: $<$ https://www. sciencedirect.com/science/article/pii/S074301670300086X?casa tok en=h2gyYaTzHWoAAAAA:3e2tSJ0xkLh58F_xacT8i9xM4Uvp-Tg5SZUZYecfa15SC2k Hf7Tx-v5iacY9FuIBfUHhxcaQ $>$. Accessed: Jul. 17, 2019. doi: 10.1016/j.jrurstud.2003.12.001.

CÁCERES, Daniel. Non-certified organic agriculture : an opportunity for resource-poor farmers? Outlook on AGRICULTURE, v.34, n.3, p.135-140, 2005. Available from: $<$ https://journals.sagepub.com/doi/abs/10.5367/000000005774378 775>. Accessed: Jul. 12, 2019. doi: 10.5367/000000005774378775.

CARMELO, Martinez. Mountain Fruits Company and Mountain Fruits Farmers Association (MonAFFA), Pakistan. Available from: <https://www.pakka.ch/en/suedpartner/mountainfruits-company-und-mountain-fruits-farmers-associationmonaffa-pakistan/>. Accessed: Aug. 17, 2019

CHAPPELL, Michael Jahi; LAVALLE, Liliana A. Food security and biodiversity : can we have both ? An agroecological analysis. Agric Hum Values, v.28, p.3-26, 2011. Available from: $<$ https:// link.springer.com/article/10.1007/s10460-009-9251-4>. Accessed: Jul. 19, 2019. doi: 10.1007/s10460-009-9251-4.

CHIN, Wynne w. The Partial Least Squares Approach to Structural Equation Modeling. California State University, Fullerton: [s.n.], 1998. Available from: <https://www.researchgate. net/publication/311766005 The Partial Least Squares Approach to_Structural_Equation_Modeling $>$. Accessed : Jul. 12, 2019.

CHMIELINSKI, Pawel et al. The land is what matters: factors driving family farms to organic production in Poland. British Food Journal, v.121, n.6, p.1354-1367, 2019. Available from:
$<$ https://www.emerald.com/insight/content/doi/10.1108/BFJ-052018-0338/full/html>. Accessed: Jul. 12, 2019. doi: 10.1108/BFJ05-2018-0338.

DAR, Mohammad Ishaq. Pakistan Economic Survey 2017. Islamabad: [s.n.], 2017. Available from: $<\mathrm{http} / / / \mathrm{www}$.finance.gov. pk/survey_1617.html>. Accessed: Oct. 7, 2019.

DAXINI, Amar et al. Understanding farmers' intentions to follow a nutrient management plan using the theory of planned behaviour. Land Use Policy, v.85, n. March, p.428-437, 2019. Available from: <https://www.sciencedirect.com/science/article/ pii/S0264837718318131? casa token=KznO7Ow YHsAAAAA :SVftxEfgHsZpvYVTDL6tSbJVT9I59GWQSuixsmcTJJQ0W4cX9C3KmUQ-SoEDuU2UasyK5mXyg>. Accessed: Jan. 17, 2020. doi: 10.1016/j.landusepol.2019.04.002.

DENG, Jian et al. Science of the Total Environment Analysis of the ecologicalconservationbehavioroffarmersinpaymentforecosystem service programs in eco-environmentally fragile areas using social psychology models. Science of the Total Environment, v.550, p.382-390, 2016. Available from: <https://www.sciencedirect. com/science/article/pii/S0048969716301516?casa_token $=98$ gPQAcSThkAAAAA:c6e4Ax1nA9YhLWQY4jFAAXLM vr1A36zQ9BvQvmqGPNPoisjyeMnAxPG1HUdrO8tksYcw>. Accessed Dec. 21, 2019. doi: 10.1016/j.scitotenv.2016.01.152.

DESSART, François J; BARREIRO-HURLÉ, Jesús; VAN BAVEL, René. Behavioural factors affecting the adoption of sustainable farming practices: a policy-oriented review. European Review of Agricultural Economics, v.46, n.3, p.417-471, 2019. Available from: <https://www.researchgate.net/profile/Francois-Dessart/ publication/334112111_Behavioural_factors_affecting_the_adoption of_sustainable_farming_practices_a_policy-oriented_review/ links/5d1759ac92851cf440552b9a/Behavioural-factors-affecting-theadoption-of-sustainable-farming-practices-a-policy-oriented-review. pdf $>$. Accessed: Jul. 12, 2019. doi: 10.1093/erae/jbz019.

FERRARA, Eliana La. Inequality and group participation : theory and evidence from rural Tanzania. Journal of Public Economics, v.85, p.235-273, 2002. Available from: $<$ https://www.sciencedirect. $\mathrm{com} /$ science/article/abs/pii/S0047272701001025?casa_token $=\mathrm{Du}$ uB8AwAHsUAAAAA:I4NSUSMXltt-W18r6VgfAeKZ ZcBqLoZ3 NXvwR7ZdK7HiD3W9jW54LyBiD7ZAX2CmjsXdJsQ9cQw>. Accessed: Jul. 12, 2019. doi: 10.1016/S0047-2727(01)00102-5.

FINLEY, Lynn et al. Does organic farming present greater opportunities for employment and community development than conventional farming? A survey-based investigation in California and Washington. Agroecology and Sustainable Food Systems, v.42, n.5, p.552-572, 2018. Available from: <http://dx.doi.org/10.1 080/21683565.2017.1394416>. Accessed: Aug. 17, 2019. <https:// www.tandfonline.com/doi/abs/10.1080/21683565.2017.1394416> doi: $10.1080 / 21683565.2017 .1394416$

FISHBEIN, Martin; AJZEN, Icek. Predicting and Changing Behavior: The Reasoned Action Approach. New York: Psychology Press. Taylor \& Francis Group, 2011. Available from: <https:// www.taylorfrancis.com/books/predicting-changing-behaviormartin-fishbein-icek-ajzen/10.4324/9780203838020>. Accessed: Jul. 12, 2019. doi: 10.4324/9780203838020.

FORNELL, Claes; LARCKER, David F. Evaluating Structural Equation Models with Unobservable Variables and Measurement Error. Journal of Marketing Research, v.18, n.1, p.39-50, 1981. Available from: <https://journals.sagepub.com/doi/abs/1 
0.1177/002224378101800104>. Accessed: Jul. 12, 2019. doi: $10.1177 / 002224378101800104$.

GREEN, Samuel B. How Many Subjects Does It Take To Do A Regression Analysis. Multivariate Behavioral Research, v.26, n.3, p.499-510, 1991. Available from: <https://www.tandfonline. com/doi/abs/10.1207/s15327906mbr2603 7>. Accessed: Jul. 12, 2019. doi: $10.1207 /$ s15327906mbr2603_7.

HAIR, Joe et al. An updated and expanded assessment of PLSSEM in information systems research. Industrial Management \& Data Systems, v.117, n.3, p.442-458, 2017. Available from: $<$ https://www.emerald.com/insight/content/doi/10.1108/IMDS04-2016-0130/full/html $>$. Accessed : Jul. 12, 2019. doi: <https:// doi.org/10.1108/IMDS-04-2016-0130>.

HAIR, Joe F. et al. An assessment of the use of partial least squares structural equation modeling in marketing research. Journal of the Academy of Marketing Science, v.40, n.3, p.414-433, 2012. Available from: <https://ink.springer.com/article/10.1007\%25 2Fs11747-011-0261-6>. Accessed: Jul. 12, 2019. doi: 10.1007/ s11747-011-0261-6.

HAIR, Joe F. et al. Partial least squares structural equation modeling (PLS-SEM): An emerging tool in business research. European Business Review, v.26, n.2, p.106-121, 2014. Available from: $<$ https://www.emerald.com/insight/content/doi/10.1108/EBR-10$2013-0128 / \mathrm{full} / \mathrm{html}$ ? $\mathrm{src}=$ recsys $\&$ fullSc $=1 \&$ fullSc $=1 \&$ fullSc $=1$ $\&$ fullSc $=1 \& \mathrm{mbSc}=1 \&$ fullSc $=1 \&$ fullSc $=1>$. Accessed : Jul. 12, 2019. doi: 10.1108/EBR-10-2013-0128.

HAIR, Joe F.; RINGLE, Christian M.; SARSTEDT, Marko. PLSSEM: Indeed a Silver Bullet. Journal of Marketing Theory and Practice, v.19, n.2, p.139-152, 2011. Available from: <https:// www.tandfonline.com/doi/full/10.2753/MTP1069-6679190202>. Accessed: Jan. 03, 2020. doi: 10.2753/MTP1069-6679190202.

HAIR, Joseph F.; RINGLE, Christian M.; SARSTEDT, Marko. Partial Least Squares Structural Equation Modeling: Rigorous Applications, Better Results and Higher Acceptance. Long Range Planning, v.46, n.1-2, p.1-12, 2013. Available from: $<$ https://papers.ssrn.com/sol3/papers.cfm?abstract_id=2233795>. Accessed: Jan. 03, 2020

HAIR JR., Joseph F. et al. Multivariate Data Analysis. [S.l: s.n.], 2010. < <ttps://digitalcommons.kennesaw.edu/facpubs/2925/>. Accessed: Oct. 1, 2019

HATTAM, Caroline E; LACOMBE, Donald J; HOLLOWAY, Garth J. Organic certification, export market access and the impacts of policy: Bayesian estimation of avocado smallholder " times-to-organic certification " in Michoac ' an Mexico. Agricultural Economics, v.43, p.439-455, 2012. Available from: $\quad<$ https://onlinelibrary.wiley.com/doi/abs/10.1111 /j.1574-0862.2012.00595.x>. Accessed : Jul. 12, 2019. doi: 10.1111/j.1574-0862.2012.00595.x.

HENSELER, Jorg. Partial Least Squares Path Modeling. Advanced $\mathrm{M}$ ed. Netherlands: Springer International Publishing, 2017. Available from: <https://link.springer.com/ chapter/10.1007/978-3-319-53469-5 12>. Accessed: Jul. 12, 2019. doi: <https://doi.org/10.1007/978-3-319-53469-5_12>.

HENSELER, Jörg; HUBONA, Geoffrey; RAY, Pauline Ash Using PLS path modeling in new technology research : updated guidelines. Industrial Management \& Data Systems, v.116, n.1, p.2-20, 2016. Available from: Accessed: Jul. 12, 2019. <https:// www.emerald.com/insight/content/doi/10.1108/IMDS-09-20150382/full/html> . doi: 10.1108/IMDS-09-2015-0382.

HENSELER, Jorg. Partial Least Squares Path Modeling. Advanced $\mathrm{M}$ ed. Netherlands: Springer International Publishing, 2017. Available from: <https://link.springer.com/ chapter/10.1007/978-3-319-53469-5_12>. Accessed: Jul. 12, 2019. doi: 10.1007/978-3-319-53469-5_12.

HENSELER, Jorg; RINGLE, Christian M.; SINKOVICS, Rudolf R. The Use of Partial Least Squares Path Modeling in International Marketing. Advances in International Marketing, v.20, n. 2009, p.277-319, 2009. Available from: $<$ https:/www.emerald.com/insight/ content/doi/10.1108/S1474-7979(2009)0000020014/full/html>. Accessed: Jul. 12, 2019. doi: 10.1108/S1474-7979(2009)0000020014.

HENSON, Spencer; MASAKURE, Oliver; CRANFIELD, John. Do Fresh Produce Exporters in Sub-Saharan Africa Benefit from GlobalGAP Certification ? World Development, v.39, n.3, p.375386, 2011. Available from: <https://www.sciencedirect.com/ science/article/pii/S0305750X10001178?casa token $=5$ UhK7E4o J10AAAAA:SWytKQUVPvzfj4TJbMZPKDbU $980 U A l o w d f-h F$ CryaedlwgG0dQUpE9S4wqwzqHKPK58pNcCCHQ>. Accessed: Oct. 13, 2019. doi: 10.1016/j.worlddev.2010.06.012.

HO, Robert. Handbook of Univariate and Multivariate Data Analysis with IBM SPSS. 6000 Broken Sound Parkway NW, Suite 300, Boca Raton, FL: CRC Press, Taylor \& Francis Group, 2014 Available from: < https://www.taylorfrancis.com/books/handbookunivariate-multivariate-data-analysis-ibm-spss-robert-ho/10.1201/ b15605>. Accessed: Jul. 12, 2019. doi: 10.1201/b15605.

HOME, Robert et al. Factors in the decision by Swiss farmers to convert to organic farming. Renewable Agricultue and Food Systems, p.1-11, 2018. Available from: <https://search. proquest.com/openview/265a260c91b58e02487d243eb4ae7ea9/1 ?pq-origsite $=$ gscholar $\&$ cbl $=51652>$. Accessed: Jul. 12, 2019. doi: $10.1017 /$ S1742170518000121.

HU, Li-tze; BENTLER, Peter M. Fit Indices in Covariance Structure Modeling: Sensitivity to Underparameterized Model Misspecification. Psychological Methods, v.3, n.4, p.424-453, 1998. Available from: <https://psycnet.apa.org/ record/1998-11538-003>. Accessed: Jul. 12, 2019.

ISSA, Irwa. Analysis of the Market Potential of Syrian Organic Fruit and Vegetables for Exports to Germany. 2016. 1-321 f. 2016. Available from: <https://d-nb.info/1119265304/34>. Accessed: Oct. 16, 2019. doi: 10.1037/1082-989X.3.4.424.

ISSA, Irwa; HAMM, Ulrich. Adoption of Organic Farming as an Opportunity for Syrian Farmers of Fresh Fruit and Vegetables : An Application of the Theory of Planned Behaviour and Structural Equation Modelling. Sustainability, p.1-22, 2017. Available from: <https://www.mdpi.com/2071-1050/9/11/2024>. Accessed: Jul. 12, 2019. doi: 10.3390/su9112024.

JOUZI, Zeynab et al. Organic Farming and Small-Scale Farmers : Main Opportunities and Challenges. Ecological Economics, v.132, p.144-154, 2017. Available from: <https://www. sciencedirect.com/science/article/pii/S0921800915306212?casa t o k e n = c w y C 5 F V C D v A A A A A A : J Q D n r 3 gOKwFuoPKyfhxfJabd_FZC_3ak8R6aHMyU5p7qrJk-8WA k2HkAbVhk3JfBxupUGNCA>. Accessed: Aug. 13, 2019. doi: 10.1016/j.ecolecon.2016.10.016. 
KASHIF, Umair et al. Consumer preferences toward organic food and the moderating role of knowledge: a case of Pakistan and Malaysia. Ciência Rural, v.50, n.5, p.1-13, 2020.

KERSELAERS, Eva et al. Modelling farm-level economic potential for conversion to organic farming. Agricultural Systems, v.94, p.671-682, 2007. Available from: <https://www.scielo.br/ scielo.php?pid=S0103-84782020000500751\&script $=$ sci arttext $>$. Accessed: Jul. 12, 2019. doi: 10.1590/0103-8478cr20190842.

KHAN, A. S.; AHMAD, S.; AMJAD, M. Prospects and Challenges of Organic Fruit Production in Pakistan. 2013, Leavenworth, USA: [s.n.], 2013. p. 57-64. Available from: <https://www.actahort.org/ books/1001/1001 4.htm>. Accessed: Jul. 12, 2019. doi: 10.17660/ ActaHortic.2013.1001.4.

KHANAL, Aditya R; MISHRA, Sachin K; HONEY, Ummey. Certified Organic food production, financial performance, and farm size: An unconditional quantile regression approach. Land Use Policy, v.78, n. July, p.367-376, 2018. Available from: $\quad<\mathrm{https} / / / \mathrm{www} . s c i e n c e d i r e c t . c o m / s c i e n c e / a r t i c l e / p i i /$ S026483771830574X? casa token $=$ CLwJhidM7BAAAAAA :pRya0qxV2Q8RY3CEYb9VYsRzHVhIkQK1gI3R8JNoD_ IHA2vhC4_e4fOLh-IFSKThz8CLpMqR0Q>. Accessed: Feb. 9, 2020. doi: 10.1016/j.landusepol.2018.07.012.

KLEEMANN, Linda; ABDULAI, Awudu. Organic Certification, agro-ecological practices and return on investment: Evidence from pineapple producers in Ghana. Ecological Economics, v.93, p.330-341, 2013. Available from: <https://www.sciencedirect. $\mathrm{com} /$ science/article/pii/S0921800913002164? casa token $=6 \mathrm{MKFu}$ Mt1RSwAAAAA:DWentNMfaqPTdp0aZ1eFaVMžnSWNrIdLiC s1pjnWzfTHUVLx-abvS-OOnTOgtnKLhssxqC-ieQ>. Accessed: Jul. 12, 2019. doi: 10.1016/j.ecolecon.2013.06.017.

KLEEMANN, Linda; ABDULAI, Awudu; BUSS, Mareike. Certification and Access to Export Markets: Adoption and Return on Investment of Organic-Certified Pineapple Farming in Ghana. World Development, v.64, p.79-92, 2014. Available from: $\quad<\mathrm{https} / / / \mathrm{www}$. sciencedirect.com/science/article/pii/ S0305750X14001260? casa_token=uorPHaIjs10AAAAA:7nWf v8gEg vHEYFJYHfiYQzJa5f3 y-523006OmnwvC5SVMf6J NI_8WshKy8_VU8q-V9Quq7g>. Accessed: Aug. 13, 2019. doi: 10.1016/j.worlddev.2014.05.005.

KOESLING, Matthias; FLATEN, Ola; LIEN, Gudbrand. Factors influencing the conversion to organic farming in Norway. International Journal of Agricultural Resources, Governance and Ecology, v.7, n.1/2, p.78-95, 2008. Available from: <https://www. inderscienceonline.com/doi/abs/10.1504/IJARGE.2008.016981>. Accessed: Jul. 12, 2019. doi: 10.1504/IJARGE.2008.016981.

KOUSAR, Rakhshanda et al. Issues and Impacts of the Apricot Value Chain on the Upland Farmers in the Himalayan Range of Pakistan. Sustainability, v.11, p.1-13, 2019. Available from: $<$ https://doi.org/10.3390/su11164482>. Accessed: Jul. 12, 2019. $<$ https://www.mdpi.com/2071-1050/11/16/4482>

LÄPPLE, Doris; RENSBURG, Tom Van. Adoption of organic farming: Are there differences between early and late adoption ? Ecological Economics, v.70, n.7, p.1406-1414, 2011. Availeable from: $\quad<$ https://www.sciencedirect.com/science/article/pii/ S0921800911000917? casa_token $=$ spW5Nr5OduoAAAAA:r lnczUYZH3QjpKz4UiiNaRj5C-BCrlaiL-bBsN0j0vfAN3nzs J TA84bs9es0XTU7zaMfzqwdQ>. Accessed: Jul. 13, 2019. doi: 10.1016/j.ecolecon.2011.03.002.
LIAO, Chechen; CHEN, Jain-Liang; YEN, David C. Theory of planning behavior (TPB) and customer satisfaction in the continued use of e-service: An integrated model. Computers in Human Behavior, v.23, n.6, p.2804-2822, 2007. Available from: $\quad<\mathrm{https}: / /$ www.sciencedirect.com/science/article/pii/ S0747563206000768? casa_token=HVZmv0O_7jNmGtw5rfFBR FdR64r8nildT2LMTHsU5JxOze5lreMBqWc8xMw>. Accessed: Jul. 12, 2019. doi: 10.1016/j.chb.2006.05.006.

LOCKE, Karen D. Grounded Theory in Management Research. [S.1: s.n.], 2001. Available from: <https://pdfs.semanticscholar.org/ f2ac/ee2ec29c549a078f95f3a032332e5bc3f68e.pdf> Accessed: Jul. 12, 2019.

LUND, Vonne; HEMLIN, Sven; LOCKERETZ, William. Organic livestock production as viewed by Swedish farmers and organic initiators. Agriculture and Human Values, v.19, n.3, p.255-268, 2002. Available from: <https://link.springer.com/ar ticle/10.1023/A:1019965907779>. Accessed : Jul. 12, 2019. doi: 10.1023/A:1019965907779.

MEIER, Matthias S et al. Environmental impacts of organic and conventional agricultural products - Are the differences captured by life cycle assessment ? Journal of Environmental Management, v.149, p.193-208, 2015. Available from: $<$ http://dx.doi.org/10.1016/j.jenvman.2014.10.006>. Accessed: November 3, 2019.

MULLER, Adrian et al. Strategies for feeding the world more sustainably with organic agriculture. Nature Communications, v.8, n.1290, p.1-12, 2017. Available from: <https://www.nature. $\mathrm{com} /$ articles/s41467-017-01410-w? org $=1364 \&$ lvl $=100 \&$ ite $=584$ $\& l e a=141599 \&$ ctr $=0 \& p a r=1 \&$ trk $=>$. Accessed: Nov. 4, 2019. doi: 10.1038/s41467-017-01410-w.

MZOUGHI, Naoufel. Farmers adoption of integrated crop protection and organic farming: Do moral and social concerns matter? Ecological Economics, v.70, n.8, p.1536-1545, 2011. Available from: <https://www.sciencedirect.com/science/article/ pii/S0921800911001054?casa_token=wtaCen5GNmEAAAAA: bbYJPwV7ih Pu2dyxWyx80AYGFA-9vtUGZ etjiR4MJE4Va dWx6eOfq-3Ld96H8gdOAV6bLmQ>. Accessed: Nov. 3, 2019. doi: 10.1016/j.ecolecon.2011.03.016.

NELSON, Jon; STOCK, Paul. Repeasantisation in The United States. Sociologia Ruralis, v.58, n.1, p.83-103, 2018. Available from: $<$ https://onlinelibrary.wiley.com/doi/abs/10.1111/soru.12132>. Accessed: Jul. 12, 2019. doi: 10.1111/soru.12132.

NIGBUR, Dennis; LYONS, Evanthia; UZZELL, David. Attitudes, norms, identity and environmental behaviour: Using an expanded theory of planned behaviour to predict participation in a kerbside recycling programme. British Journal of Social Psychology, v.49, n.2, p.259-284, 2010. Available from: < https://bpspsychub.onlinelibrary.wiley.com/doi/ abs/10.1348/014466609X449395>. Accessed: Jul. 12, 2019. doi: $<$ https://doi.org/10.1348/014466609X449395>.

OELOFSE, Myles et al. Certified organic agriculture in China and Brazil: Market accessibility and outcomes following adoption. Ecological Economics, p.1-9, 2010. Available from: $\quad<\mathrm{https}: / /$ www.sciencedirect.com/science/article/pii/ S092180091000159X?casa_token=_cnhHkQv4BwAAAAA:8G31 wSC0eHDwVNMfCmI-J8uwashDJaO56nzqQe7z2pNEyZwpcRs aEMA0uwwBaWoRDVyOyyaF4Q > . Accessed: Jul. 12, 2019. doi: 10.1016/j.ecolecon.2010.04.016. 
PADEL, Susanne. Conversion to Organic Farming: A Typical Example of the Diffusion of an Innovation? Sociologia Ruralis, v.41, n.1, p.40-61, 2001. Available from: <https://onlinelibrary. wiley.com/doi/abs/10.1111/1467-9523.00169>. Accessed: Jul. 15, 2019. doi: $10.1111 / 1467-9523.00169$

PENG, David Ziaosong; LAI, Fujun. Using partial least squares in operations management research: A practical guideline and summary of past research. Journal of Operations Management, v.30, p.467-480, 2012. Available from: <https://www.sciencedirect.com/science/ article/abs/pii/S0272696312000526? casa_token $=$ ir8uNgE_ HqoAAAAA:Wx2iq Wa31JVw4ZjhxKBTEFMM7W47JTeJ rrVOYbIsDO26tRLOJB-EOcnSMCP1o8dKsQtNCWVA>. Accessed: August 13, 2019. doi: 10.1016/j.jom.2012.06.002.

RASUL, Golam; HUSSAIN, Abid. Sustainable Food Security in the Mountains of Pakistan : Towards a Policy Framework. Ecology of Food and Nutrition, v.00, n.1-19, 2015. Available from: $<$ https:// www.tandfonline.com/doi/full/10.1080/03670244.2015.1052426> . Accessed: Jul. 12, 2019. doi: 10.1080/03670244.2015.1052426.

RECHE, $\mathrm{J}$ et al. Effects of organic and conventional farming on the physicochemical and functional properties of jujube fruit. LWT - Food Science and Technology, v.99, p.438-444, 2019. Available from: <https://www.sciencedirect.com/science/article/ pii/S002364381830848X?casa_token=EuR6I_WyeYIAAAA A:1QW2o1NJUHgTo7E4e2zKgJU -KQMa4JUT4kpPKnf1DrCfFksAMtgN4lSVAu5VNzrpW6arp8HA $>$. Accessed: Jan. 5, 2020. doi: 10.1016/j.lwt.2018.10.012

RIGBY, Dan; YOUNG, Trevor; BURTON, Michael. The development of and prospects for organic farming in the UK. v.26, p.599-613, 2001. Available from: <https://www.sciencedirect.com/ science/article/pii/S0306919201000239? casa token $=$ q4nGXY9M HIIAAAAA:IvTrJPcA6aaNDhjBOLcxgU_QsDaq5OiuQhYxZrd6NLHkB 9RjSbWPE_ztOP6AFXPpsrT0Xvg $>$. Accessed: Jul. 12, 2019. doi: 10.1016/S0306-9192(01)00023-9.

SARKER, M A; ITOHARA, Y; HOQUE, M. Determinants of adoption decisions: The case of organic farming ( $\mathrm{OF}$ ) in Bangladesh. Extension Farming Systems Journal, v.5, n.2, p.39-46, 2009. Available from: <https://search.informit.org/doi/ abs/10.3316/informit.733506527698660>. Accessed: Jul. 12, 2019.
SZOLNOKI, Gergely; HOFFMANN, Dieter. Online, face-to-face and telephone surveys - Comparing different sampling methods in wine consumer research. Wine Economics and Policy, v.2, n.2, p.57-66, 2013. Available from: <https://www.sciencedirect. com/science/article/pii/S2212977413000331>. Accessed: Jan. 15, 2020. doi: 10.1016/j.wep.2013.10.001

TABACHNICK, Barbara G.; FIDELL, Linda S. Using Multivariate Statistics. [S.1: s.n.], 2014. Available from: $<$ https:// www.pearsonhighered.com/assets/preface/0/1/3/4/0134790545. pdf>. Accessed: Feb. 12, 2020.

TENENHAUS, Michel et al. PLS path modeling. Computational Statistics \& Data Analysis, v.48, p.159205, 2005. Available from: <https://www.sciencedirect.com/ science/article/pii/S0167947304000519?casa_token $=\mathrm{s} 31 \mathrm{cX}$ 6g sLCYAAAAA:9tS0vKnI9f1dfsUXcmYMoZh5BHcfcMalv q2BGFc9spEizq1DPoT1k64uDE3tzW99Jpp53W1sg>. Accessed: Jul. 12, 2019. doi: 10.1016/j.csda.2004.03.005.

TERANO, Rika et al. Factors Influencing Intention to Adopt Sustainable Agriculture Practices among Paddy Farmers in Kada , Malaysia. Asian Journal of Agricultural Research, v.9, n.5, p.268-275, 2015. Available from: <https://www.researchgate. net/profile/Rika-Terano-3/publication/282962727 Factors Influencing_Intention_to_Adopt_Sustainable_Agriculture Practices among Paddy Farmers in Kada Malaysia/ links/567519cf08ae0ad265bd5e76/Factors-Influencing-Intentionto-Adopt-Sustainable-Agriculture-Practices-among-PaddyFarmers-in-Kada-Malaysia.pdf $>$. Accessed: Oct. 14, 2019. doi: 10.3923/ajar.2015.268.275

WILIER, Helga; GILLMOR, Desmond A. Organic Agriculture in the Republic of Ireland. Irish Geography, v.25, n.2, p.149159, 1992. Available from: <https://www.tandfonline.com/doi/ abs/10.1080/00750779209478727>. Accessed: Jul. 12, 2019. doi: $10.1080 / 00750779209478727$.

WILLER, Helga; LERNOUD, Julia. The World of Organic Agriculture: Statistics and Emerging Trends 2019. Research Institute of Organic Agriculture (FiBL). Frick, Switzerland: [s.n.], 2019. Available from: <https://orgprints.org/37018/>. Accessed: Nov. 11, 2019. 